\title{
Special Issue: VIII Congress ACCID and APC
}

\author{
Francesc Gómez Valls in \\ President of the "Agrupacio de Professorat de Comptabilitat i Control" and \\ member of the management board of ACCID (Spain) \\ francesc.gomez@uab.cat
}

Received November, 2020

Accepted November, 2020

The articles presented in this issue of Intangible Capital are included in of the set contributions that were submitted for the consideration of those attending the VIII ACCID Congress and APC Conference: new times, new opportunities, which held at the IQS School of Management on June 6-7, 2019, with a participation of more than 600 academics and professionals.

Of the papers submitted, a total of three have been selected, which examine difference topics that are included in various disciplines involved in the general field of Accounting (Non-financial Information and Sustainability, Costs and Educations, Financial Information, Business Success and Failure, Solvency and Family Business, Sector Analysis, Accounting History, Recognition and Measurement Standards and Free Cash Flow). In each case, the work is the product of the efforts of one or more authors. All are employed by universities in Catalonia or other European universities.

The first article deals with a retrospective study of the association and accounting knowledge in Catalonia, during the period 1924-1940. The study analyses the magazine "Organització" published by the Association of Accountants of Catalonia (ACC). The study highlights the role of ACC as a driving force in the accounting profession between 1924 and 1940 (also as an example of the dynamism of Catalan society during that period).

Finally, the study allows us to find similarities and differences between the ancient ACC and the current ACCID and shows that at certain times the associations of accountants has been important by the academics and the profession.

The second paper analyses the Empirical Evolution of credit risk over a decade in ibex 35 companies and its relationship with the qualifications of its ratings. It has two objectives.

Firstly, it describes the evolution of the main economic-financial indicators that influence credit risk for a sample of 10 Spanish companies listed on the IBEX 35. The samples were studied from a comparative period of 10 years, and based on the post-economic crisis (2012-2015) and concerning to the pre-crisis stage (2002-2005). The second objective is evaluated by considering the response to the relationship of the credit risk variable, with the name "insolvency" for its statistical analysis and is visualized through the provisions for insolvencies, the balance pending collection, the total of the investments, the result of the year and the net amount of the turnover. These variables are all reflected in the different economic-financial ratios and are ordered regarding to their ratings, as provided by the internationally credit rating agency, Standards \& Poor's (S\&P).

Finally, the third work aims to determine the influence of Intellectual Capital (IC) and its components' impact on Portuguese tourism organizations' business performance through Return on the assets (ROA). In other words, the paper examines the impact of effective utilization of IC on financial performance, analysing the relationship between IC and financial performance in the hospitality and tourism industry. To conduct this research the practical data were obtained from the SABI database. The authors have collected economic and financial information from balance sheets and financial reports of 46.951 Portuguese companies during 2016. Multiple 
regression analysis were introduced in order to identify the effect of IC components that contribute to the company performance.

Each meeting of the ACCID (whether it is a conference or workshop, as in this case) represents an activity dedicated to the field of Accounting and Business Management. Evidence of this papers offered in this issue of the Intangible Capital journal, which offer readers a glimpse of the session held, their content and the level reached.

\section{Declaration of Conflicting Interests}

The author declared no potential conflicts of interest with respect to the research, authorship, and/or publication of this article.

\section{Funding}

The author received no financial support for the research, authorship, and/or publication of this article.

\section{To cite this article:}

Gómez Valls, F. (2020). Special Issue: VIII Congress ACCID and APC. Intangible Capital, 16(2), 43-44. https://doi.org/10.3926/ic.1718

Article's contents are provided on an Attribution-Non Commercial 4.0 Creative commons International License. Readers are allowed to copy, distribute and communicate article's contents, provided the author's and Intangible Capital's names are included. It must not be used for commercial purposes. To see the complete license contents, please visit https://creativecommons.org/licenses/by-nc/4.0/. 